\title{
Sociolinguistic and Economic Dimensions in Cross-Border Trade between the DR Congo and Zambia
}

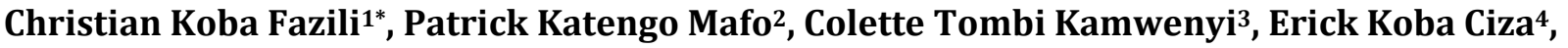 Maurice Muyaya Wetu ${ }^{1,5}$, Déogratias Ilunga Yolola Talwa ${ }^{1,5}$}

\author{
${ }^{1}$ Department of Languages and Business, Faculty of Letters and Human Sciences, University of Lubumbashi, Lubumbashi, \\ Democratic Republic of Congo \\ ${ }^{2}$ Department of Accounting, Higher Institute of Commerce of Lubumbashi, Lubumbashi, Democratic Republic of Congo \\ ${ }^{3}$ Department of SIC \& Languages and Business, Faculty of Letters and Human Sciences, University of Kolwezi, Kolwezi, \\ Democratic Republic of Congo \\ ${ }^{4}$ Computer Network Management, Higher Institute of Commerce of Lubumbashi, Lubumbashi, Democratic Republic of Congo \\ ${ }^{5}$ Department of French Languages and Civilizations, Faculty of Letters and Human Sciences, University of Lubumbashi, \\ Lubumbashi, Democratic Republic of Congo \\ Email: *christiankoba@gmail.com
}

How to cite this paper: Fazili, C.K., Mafo, P.K., Kamwenyi, C.T., Ciza, E.K., Wetu, M.M. and Talwa, D.I.Y. (2020) Sociolinguistic and Economic Dimensions in Cross-Border Trade between the DR Congo and Zambia. Open Access Library Journal, 7: e6953.

https://doi.org/10.4236/oalib.1106953

Received: October 31, 2020

Accepted: December 28, 2020

Published: December 31, 2020

Copyright $\odot 2020$ by author(s) and Open Access Library Inc.

This work is licensed under the Creative Commons Attribution International License (CC BY 4.0).

http://creativecommons.org/licenses/by/4.0/

(c) $\underset{\mathrm{By}}{\mathrm{By}}$ Open Access

\begin{abstract}
This article identifies key factors that can reduce customs fraud by analyzing the correlations that exist in front of certain dependent variables, namely language, cultural contact, intra linguistic and anthropological, sustainable human development, sale, purchase, transportation, declaration of primary products (food crops), and the relationship between the Democratic Republic of Congo and Zambia, their institutional framework with a specific application to the case of Kasumbalesa border. Our research presented and discussed the theoretical and empirical literature on the subject. We have structured our analysis on the subject around five axes, based on estimates of equations that measure the vehicle of linguistic patterns, cultural, anthropological and business, institutional efficiency and socio-economic conditions. We first studied the impact of languages on cross-border trade, then the influence of this one on the sale, purchase, transportation and declaration of supposed primary products and finally the influence of it on the emergence of customs fraud. From this analysis, it emerges from the results that borders are not limits in themselves, but quite the contrary of gateways, voices of linguistic, anthropological and cultural continuity. Language, with all of its components, is the key that traders use for performance in cross-border trade. This one can facilitate fraud at all levels at customs and if is taken as a cultural mechanism by the state to strengthen existing traditional mechanisms, it can help to fight
\end{abstract}


fraud. A tax evasion with a well-orchestrated fraud is seen on the pedestrian street commonly called Bilanga by some users. The increase in trade volumes for primary products should in principle lead to a relative improvement in the level of revenue generated by the Congolese state, but unfortunately the opposite is seen. The business environment is very relevant in view of the theoretical foundations compared to the existing economic model, based on economic and sociolinguistic liberalism.

\section{Subject Areas}

International Economics

\section{Keywords}

Sociolinguistics, Economy, International Trade, Cross-Border Trade, International Relationship

\section{Introduction}

The DRC has a particular geographical situation in Africa and in the world, this situation is the consequence of a random delineation of borders which targeted more economic than socio-cultural motives in so far as communities found themselves on both sides of the borders (example of the Bemba in Congo and Zambia, Tabwa, Lamba, etc.) The geographical proximity with its neighbors means that from a cultural and linguistic point of view, the nine countries have similarities. Sharing its borders with nine countries has a number of consequences. This situation has meant that these cross-border communities who share a common base of socio-cultural values, although artificially separated by these borders, they continue to consider each other as brothers. This is the case of the border area of Kasumbalesa in the Haut-Katanga Province.

The border area of Kasumbalesa constitutes an important trade point between Zambia, Tanzania and all the other countries of southern Africa so that from the flows of men and women are added to them their cultures and their languages, which thus cause confusion of identity and identification of nationals and foreigners on both sides of the border in regards to the supply of economic goods and services. And one thing leading to another, this confusion maintained by these cultural and linguistic aspects contributes to the perpetuation of customs fraud. Exchanges are taken in its general sense, not only economic but also cultural exchange. They are similarly sociological, anthropological, cultural, and linguistic elements in the geographically close communities.

No country can live in a vacuum. The economic concept involves the import and export of goods. The border here shows a demarcation but not an end. A bit like Papa Wemba sang, "Ebale Ya Congo ezali lopango te, Eza se nzela". The vocation of the road is to transport from one pole to another not only from an economic point of view but the road is also a vehicle of linguistic and cultural 
schemes. Linguistic and cultural elements from here move elsewhere, and those elsewhere move here. A cross-border culture is developing at the border with regard to all its social and economic practices.

The commercial effervescence at the border is to a large extent the so-called "informal", "parallel" or "second" economy [1] which has been studied from various angles: sociological, political, economic and geographic.

The sociological or anthropological approach [1] [2] generally emphasizes the strategies and profiles of actors (traders, transporters), often based on biographical interviews. A more economic analysis pays more attention to trade flows and examines price changes in markets and currency exchange rate fluctuations using statistical tools [3]. Studies focused on political questions [4] seek to make the link between the flowering of private initiatives (trade, companies) and the problem of the State; the vitality of private initiatives is sometimes seen as a palliative or a response to the dysfunction of state supervisory structures. The geographical approach [5], attached to the spatial translations of the observed phenomena, prefers to underline the reconfiguration of the exchange spaces which is currently being carried out in favor of the borderlands. Taking an anthropological approach, I propose here to analyze two cross-border aspects based on the transfer of cultural and linguistic schemes on one side and trade on the other, and to trace their genesis. The following micro socio-linguistico-economic study is devoted to the DR Congo-Zambia area, articulated around the Kasumbales market, a cross-border area which constitutes the strong point of the area and of the country.

\section{Literature Review}

The theory of speech acts has greatly contributed to the popularity of sociolinguistic approaches. It is a philosophical approach that attempts to explain in general terms certain properties of human language. It thus finds its origin in the book of the English philosopher John Langshaw [6]. If for the philosophy of language, we use language to affirm, J. L. AUSTIN notes that in speaking we do something other than just affirm: we promise, we apologize, we warn, etc. For his part, [7] attempts to broaden AUSTIN's propositions conceiving the theory of speech acts starting from the same fundamental idea. The theory of speech acts then approaches another social theory: that of communicative action which shows that communicating does not initially consist in inviting information, but in creating, prolonging, modifying social relations, in taking position etc.

The theory of speech acts is appropriate for this research, as we will analyze the languages used in cross-border trade, how languages enable cultural exchanges and transfers, social interactions and more inclusion in each other's world., without the intention of influencing the other in any way. This indirect or implicit act makes it possible not to give the impression of exerting pressure on his interlocutor, which leaves the freedom to himself choose a particular product or service in any given language. Language is an act because it produces 
effect as well as meaning (1979). This is how the freedom to express oneself in all the languages that we master, brings us anthropologically and culturally closer to our interlocutors.

This research combines two economic theories to support it. The traditional theory of international trade according to [8], who say that the genesis of the development of currently known economic thought, is to be read in two major stages, one of which is to be located, essentially between the 18th century and the other in the first half of the XXth century marked by the manifestation of the traditional theory of international trade which consolidated free trade policies favorable in particular to regional integration [9].

The new theory of international trade, in the 1980s, was initiated by Krugman P., this "new theory" by being an extension of the so-called traditional theories but by integrating the new characteristics of international trade, namely:

- Intra-industry trade within developed countries.

- Considering the importance of MNCs, which in 2005 represented nearly two thirds of world trade in goods [10].

- The reference to increasing returns to scale, contrary to the traditional theory which assumes constant returns to scale.

- The concept of product differentiation.

- The abandonment of the hypothesis of pure and perfect competition in favor of the more realistic hypothesis of imperfect competition.

Compared to previous theories, two new elements of analysis appear to explain international specialization, namely increasing returns to scale and product differentiation. The limits recorded in the explanation of traditional theories are justified by the important developments in contemporary international trade, which have caused the evolution of theoretical currents. Of these limits, it is worth mentioning:

- International specialization born from the pre-existence of comparative advantages justifies the benefit of free trade. This specialization is therefore considered to be an "exogenous" factor since it does not depend on the economic process.

- The difference between nations explains their need to exchange and only nations exchange (concealment of the role of the firm).

Consequently, the new theory of international trade greatly opens the door to new sources of gain in cross-border trade and constitutes on the whole a theoretical corpus clearly favorable to the opening of economies, even if certain models highlight configurations of ambiguity, even exchange losses [11]. In the "new" theory of international trade, the effects of openness to trade pass through more diverse channels [12]. The result is a widening of consumer choices, which increases their well-being because of their taste for the variety [11], or because it allows them to get closer to their ideal variety [13]. However, some models emphasize the possibility of ambiguities or opposite results in this regard in specific cases [14]. 


\section{Methodology}

To carry out this analytical framework, our research method chose to do a case study. With as constructivist and pragmatic cognitive method, systemic method, statistical method, critical or historical method, structural-functional method and triangulation. The case study is suitable for researchers to answer questions like "how" and "why" [15]. In particular, points out that several cases reinforce the results by replicating the filtering, thereby increasing confidence in the robustness of the theory. This is why the case study is an important integrated learning tool alongside the theoretical elements [16]. We consider it appropriate to use the case study as a methodology to describe the economic, cultural, linguistic and social reality in cross-border trade at the Kasumbalesa border.

The approach is understood as an intellectual process involving neither step, nor systematic path, nor particular rigor [17], under two manifestations to produce data or empirical evidence in the human sciences: the qualitative and the quantitative [18]. For this research we used four approaches, namely: the qualitative approach, the statistical quantitative approach and the mixed (hybrid) approach.

\section{Results}

This section is devoted to the presentation of the data, their analysis and their interpretation. The field data analysis was assisted by the SPSS computer tool, and was discussed according to the objectives of our study identified in our introduction. The data or information requested and collected during the survey was presented in tabular and graphical form. This section revealed the opinions, points of view of the users of the Kasumbalesa border regarding customs fraud, the transfer of cultural and language patterns in cross-border trade in this part of the DRC.

One hundred and twenty (120) questionnaires made by the researcher in accordance to the topic were distributed and one hundred and two (102) were returned to us. The hundred and two (102) questionnaires that we had in our possession of the participants gave us an $85 \%$ response rate, this is considered an excellent rate in a survey. Best and Khan consider the $50 \%$ rate to be fair, while $60 \%$ is considered good, $70 \%$ is considered very good, and finally $85 \%$ response rate is considered excellent.

Two key points of our investigation are important with regard to our field study. On the one hand, we sought information on the overall status of the individuals surveyed. On the other hand, we gathered their opinions on the issue of cultural patterns, the mapping of customs fraud and cross-border trade in Kasumbalesa. They were able to tell us how and how cultural patterns influence trade and cross-border mobility. And how cultural schemes can contribute to customs fraud and/or its reduction. The good command of languages introduces us into a coded circuit of cross-border languages contributing to the customs mafia. Language refers us to cultural and anthropological aspects. The better to 
defraud, the interviewees told us, you must first integrate into the language system of all the state services present on the "Bilanga" pedestrian street.

Graph 1 shows us that the age group most interested in this issue of cross-border trade and fraud was 30-39 years old. This study shows that individuals in this category better understand this issue and the Congolese customs system. The majority of these individuals has studied, or have a fairly high level of study. They better understand how the business of large and small traders works. As we had already pointed out, this is explained by the fact that in this age group most of these young people have studied and have long been looking for work, and have not found it, and end up to engage in a legal or illegal trade to earn their daily bread.

\section{Discussion}

\subsection{On the Sociolinguistic Level}

By analyzing the correlations that exist in front of certain dependent variables, namely language, cultural and intralinguistic contact, sustainable human development, sale, purchase, transport, declaration of primary products (food crops) and the institutional framework, with A specific application to the case of the Kasumbalesa border in the Democratic Republic of Congo, this research presented and discussed an abundant theoretical and empirical literature on the subject.

Structured around five axes, the analysis on the subject made on the basis of estimates of the equations that measure linguistic, cultural and commercial exchanges, institutional efficiency and socio-economic conditions first studies 1) the impact languages on cross-border trade, 2) then the influence of the latter on the sale, 3) the purchase, transport and 4) the declaration of said primary products and finally 5) the influence of the latter on the emergence of sustainable human development.

As a percentage of the most widely spoken international language on the Kasumbalesa border after calculating the impact of the language would be English with $48.9 \%$, French at $44.1 \%$, Arabic $2.9 \%$ and l' other languages $4.1 \%$. English remains above French in the buying and selling of products like "beverage" drinks. It is imperative to note here some languages (Portuguese, Italian, Spanish) that we have not specified for this study on cross-border trade. We met

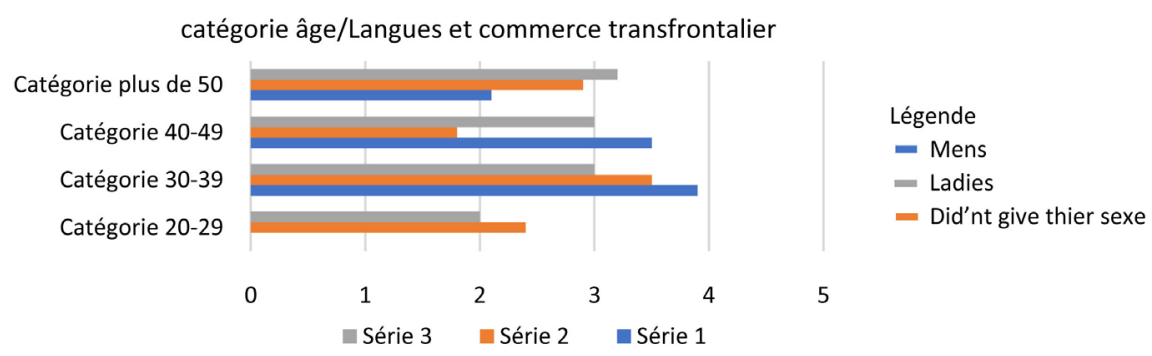

Graph 1. Age category/Languages and cross-border trade. 
them on the ground. They are practiced by the individuals surveyed and it seemed necessary to us to mention them here.

Regarding the national or African languages most spoken at the Kasumbalesa border, field data showed us that among the languages we had selected for this study, the most spoken language is Swahili, followed by Lingala, then tshiluba, and finally bemba. The high percentage of Lingala and Tshiluba at the Kasumbalesa border is explained by the presence of a large number of Kinois and Luba from Kasai in search of social stability who have migrated to this region, the latter to intercultural and especially inters linguistic contacts imposed a certain culture. This explains the strong presence of languages (Lingala and Tshiluba) in this part of the country and which have a preponderant growth.

The hypothesis according to which French and/or English alone would allow good cross-border mobility would be false, in such circumstances, mastery of several languages would be required to avoid any border nuisance. To do a good business, after analyzing the responses of individuals in the field, we have come to see that the association of several languages facilitates business and commerce in the general sense. Using a local language mixed with a so-called international vernacular, for example Swahili with another language, such as English, or Bemba, at the same time, would facilitate communication with an interlocutor who also tries to communicate and trade.

From this analysis, it emerges that borders are not limits in themselves, but quite the contrary of bridges, voices of linguistic and cultural continuity. Language with all of its components is the key that traders and all other actors use for performance in cross-border trade. They use all the languages they master to allow good communication. In other words, in bilingualism there is not only the simultaneous presence of two or more languages, but also the effective use of these different languages.

\subsection{On the Economic Plan}

The individuals interviewed in this study have given us considerable economic insight into customs fraud and tax evasion, such as the fragility of customs services, legal rigor at the border, the asymmetry of information and communication which is biased by misunderstood of languages sometimes of some traders. The methods of data analysis assume a particular organization of data, natural, but difficult to achieve according to an application of the data. What we have set out to do economically is to synthetically represent large digital sets to facilitate the operator in his decisions. In fact, the numerical sets, the methods of data analysis also propose to process qualitative data, which makes them methods capable of considering a large number of problems.

It is therefore important to note at this level of this analysis that importation into the province of Haut-Katanga is important in terms of the realization resulting from its operations, because we operate in an open economy, that is to say oriented towards outside. A very low representativeness of exports despite 
the thousands of tonnes of raw materials semi-finished products exported every day, which is very curious. This is how the present phase consists of giving language to the data on the economic dimension collected, by linking the data collected to our hypotheses and to the problematic.

Table 1 illustrates the result on the factors explaining the effects of fraud at the Kasumbalesa border post. Those interviewed attributed $16 \%$ of the facts encouraging fraud to the attraction effects by border users (drawing public attention to the acceptance of certain practices). The $16 \%$ of the words used designate the fragility of customs services and legal rigor at the Kasumbalesa border. 13\% of the words used designating the multiplicity of border services (DGDA, OCC, DGM, hygiene service, Anti-fraud, loading and loading service, Major service, Mobil, COM, border police, etc. $15 \%$ of the words used designating the asymmetry of information and communication which is biased by languages sometimes misunderstood by some users, hence the need to be in the language (coded messages) of the people present on the pedestrian in state services. $15 \%$ of the words used to designate high unemployment among young people, 15\% designating the large post "Bilanga" as the paradise of fraudsters nicknamed "hitters." And finally, $10 \%$ of the words used designating maximization of profit for taxpayers this is how all these frequencies have been included in the mapping of the themes below (Graph 2).

Table 1. Endogenous factors.

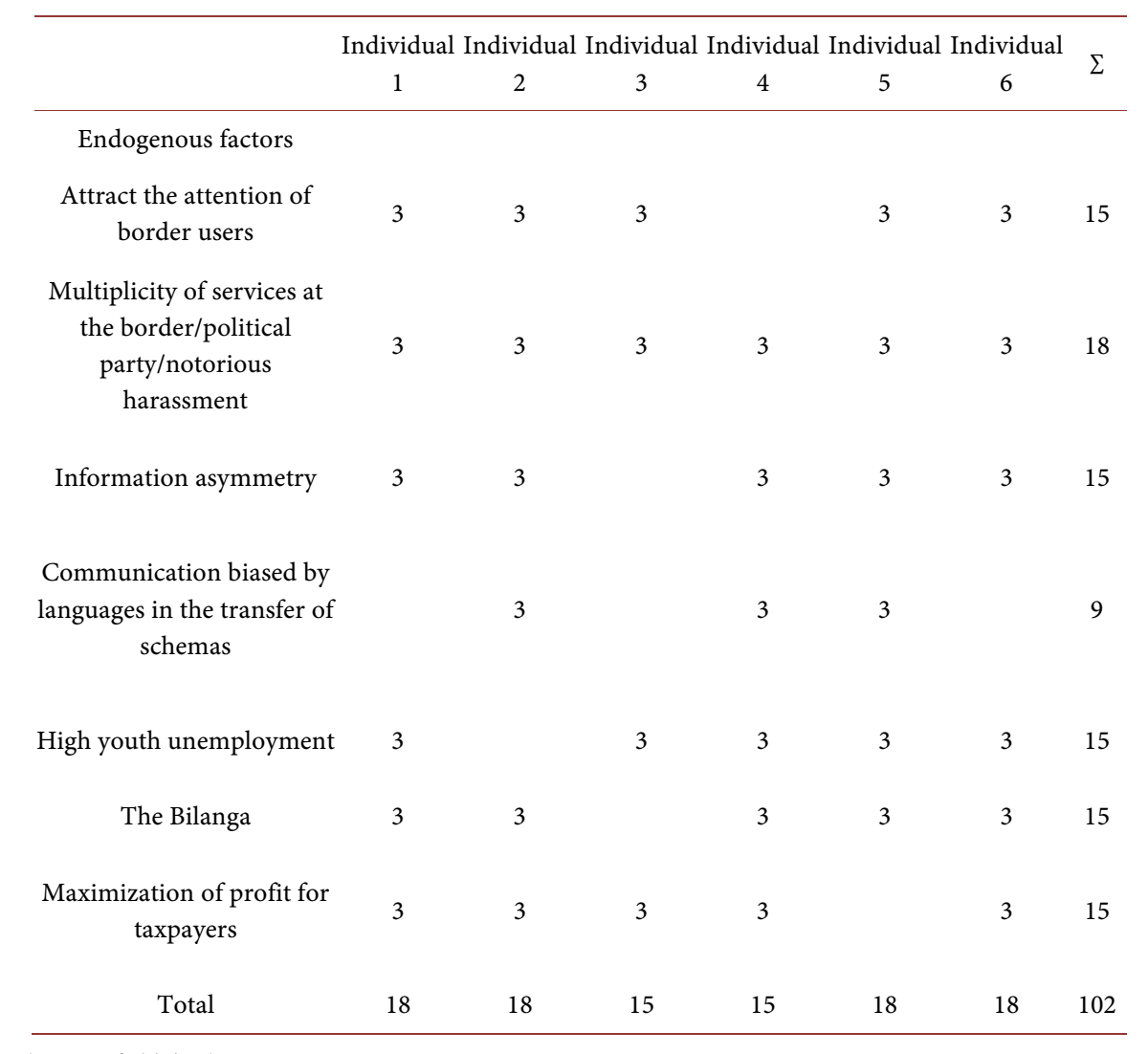

(Source: field data). 


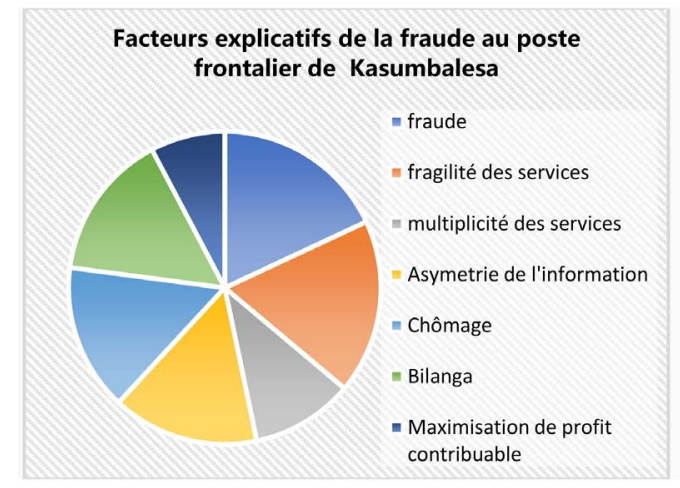

Fraud: $16 \%$

Fragility of services: $16 \%$ Multiplicity of services: $13 \%$ Information Asymetry: 15\% Unemployment: $15 \%$ Bilanga: $15 \%$

Maximization of profit: $10 \%$

Graph 2. Mapping factors.

\subsection{Mapping Factor}

It is ambiguous to evolve in an economic system that is primarily single producer and does not reach a level allowing the dynamics of the accompanying sectors (even if at a very low level of representativeness) of the single mining sector which is the lung of the Congolese economy. currently. According to Transparency International, DR Congo is currently the 16th out of 180 listed countries, being in a range of 20 to 29 points on a scale of 100 . In other words, DR Congo is among the 19 most corrupt countries in the world. However, no one can deny the existence of this phenomenon despite the synonymous term used, it is indeed in place.

According to the adviser to the honorary head of state for the fight against corruption, Emmanuel Luzolo Bambi, fraud costs the Democratic Republic of Congo up to $\$ 15$ billion each year. This is twice the state budget at present, yet we can estimate that the underground economy (i.e. the illegal economy + the black economy) represents about $3.8 \%$ of the gross domestic product (GDP) in Belgium, i.e. 12.9 billion and 3\% of GDP in Holland, [19]. Tax evasion is at the base of the destabilization of the public administration with the consequence of the dismissal of certain executives to justify the necessary in the economic circuit in order to increase the speed of its operating cycle, this makes us experience an absence of innovations and improvement of socio-economic conditions, in short, a slowdown in economic growth.

The above cycle (Graph 3) illustrates what is not applicable in our country in general and in the province of Haut-Katanga in particular. What would be plausible and conceivable to do in order to overcome the problems that paralyze the economy of the state, which is unable to carry out all its projects, and to implement and properly explain the existence of a barrier blocking the penetration of certain stages of the cycle illustrated above. The consequences will be the wide development of the avoidance of taxes and/or taxes by certain large border users who monopolize a growing share of income, profits and wealth are very numerous. A first consequence, too often forgotten or neglected, is the situation of generalized inequalities which will result from the accentuation of high-level tax fraud and evasion. It can also take place within the economy of the SADC region 


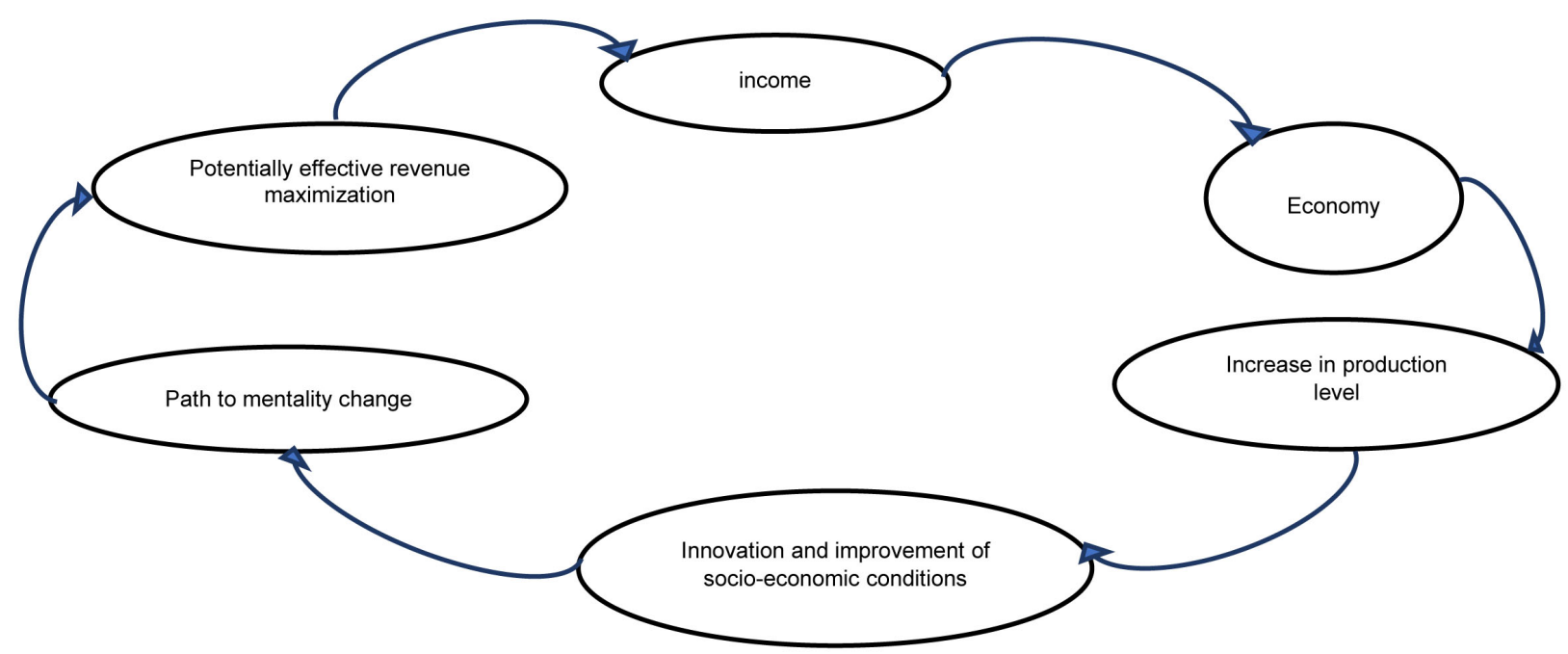

Graph 3. Cycle of socio-economic conditions.

and the world. When multinationals pay very little tax compared to SMEs, it is unfair competition. This advantage will have multiple consequences, in terms of access to public markets for example, and also in terms of the prices offered to customers.

A consequence, very direct and visible, even if it is difficult to measure with forecast, is an absence of budgetary revenues for the States and the public authorities. Faced with this situation, the political powers will both tax more heavily people who cannot defraud (employees, retirees, consumers, etc.) and reduce certain public spending (governments will say that budgetary savings must be made. , that we must not live beyond our means, that we must not leave debts to our children, etc.) in any event, what will have been defrauded by some will end up being paid by the others, either directly through increased tax pressure, or indirectly through a reduction in certain public spending and certain public services [20].

\section{Conclusions}

This questioning is the very real manifestation of a doubt about the result of this work. We are in the situation of the spectator for whom the word "end" which appears on the screen triggers the beginning of his reflection [21]. To conclude would then be a way of starting over.

We believe, at least we think so that we have shown throughout this article that the border is not this simple line manipulated both by the State and by border populations, the border residents. Far from being simply a socio-linguistic and economic phenomenon of Kasumbalesa, it is above all a social phenomenon. This article relating to the knowledge of border economic activities between DR Congo and Zambia can be analyzed from different angles: economic, anthropological, inter-linguistic, and sociological. But for our part, our objective being to identify all the phenomena which appear or which are current on the 
margins, the border must be considered in a regional framework [22].

In the context of trade between DR Congo and Zambia, flows on the Kasumbalesa pedestrian route are hardly counted and controlled at the various border crossings. The main actors representing the state to which this work has been entrusted are customs officials, DGM agents, pedestrian services, border police and anti-fraud officers. The former provides the state with revenue to establish its operating budget, by controlling, accounting for and taxing foreign products according to the laws in force on trade. They thus play a role as protector of the state's internal markets.

One of the activities that take place on the border margins of states is commerce. This is the result of the differential created by the functionalized border and which cross-border workers exploit at will. Whether official or not, cross-border trade contributes to the well-being of populations. Many factors slow down the dynamism of exchanges, factors of a political, inter-linguistic, anthropological and economic-cultural nature. Moreover, the study on the transfer of cross-border language schemas as a social factor should consider the individuals who use it (how, in what circumstances). The best would be to take the languages as a couple (two to two) or more for more ease in the trade. In other words, in this bilingual situation, there is not only the simultaneous presence of two or more languages, but also the effective use of these different languages in a business.

Far from allowing official intercultural exchanges, we are witnessing the rise of very informal local exchanges between users. Traditional flows linked to productive complementarities allow the reduction of food tensions that may arise. This type of trade, initially very small in terms of the importance of flows, concerns products that have long fueled trade in the Zambia-Congo direction (flour, sugar, salt). This is a convenience store.

Cross-border trade, however you qualify it, informal, ant, contraband, unregistered, Ngulu, cope, Tindikage or its unstructured nature, is an activity that participates in social regulation, especially in this period of acute crisis. due to the Covid19 pandemic in our country which is concerned by this article. With the drying up of public service jobs since the December 2018 elections and the direct or indirect effects of the crisis in Congo, the retail sale of imported goods is a source of jobs and income for the deflated of companies and young graduates or not. The border, long owned by the state, is changing hands for that of border workers. From a source of state revenue, it becomes a source of foreign exchange and jobs for a large segment of the population.

The existing economic model keeps the Congolese economy heavily dependent on export earnings from mining products, the import of basic or food products not only facilitates the flight of capital but also a well-orchestrated customs fraud on the commonly known pedestrian route. Bilanga by some large, small traders and other facilitators. The increase in trade volumes for primary products should in principle lead to a relative improvement in the level of revenue generated by the Congolese state, but unfortunately the opposite is seen. 
The contribution of our article shows that the border produces a physical space where transgressive practices take place. To achieve this, the use of several is a beneficial and facilitating factor in this process. Border economic activities, whether official or not, undoubtedly create flows and solidarity. The more a border is rigid, monitored, functionalized, the more the transgressive practices which are linked to its presence by the transfer of cultural schemes are strong. This article does not mark the end but the beginning of other perspectives of analysis. It is intended to be a contribution to the knowledge of linguistic, anthropological and economic border activities between the DRC and Zambia, especially for the SADC zone.

\section{Authors Contribution}

All of the authors of this article made significant contributions to the design, implementation and/or analysis and interpretation of the data, article development, and review criticism of its intellectual content.

\section{Contributors}

Study design: Christian KOBA Fazili, Patrick KATENGO Mafo, Colette TOMBI Kamwenyi, Déogratias ILUNGA Yolola Talwa, Maurice MUYAYA Wetu.

Data collection: Christian KOBA Fazili, Erick KOBA Ciza, Patrick KATENGO Mafo.

Data analysis: Christian KOBA Fazili, Déogratias ILUNGA Yolola Talwa, Patrick KATENGO Mafo, Colette TOMBI Kamwenyi.

\section{Drafting of the Manuscript}

All authors.

\section{Conflicts of Interest}

The authors declare no conflict of interest.

\section{References}

[1] Mac Gaffey, J. (1987) Entrepreneurs and Parasites. Cambridge University Press, Cambridge.

[2] Arditi, H.I. and Gaffey, M. (1991) Un marché au carrefour de frontières multiples Karine Bennafla, Mbaiboum, 61.

[3] Herrera, J. (2017) Les échanges transfrontaliers entre le Cameroun et le Nigeria depuis la dévaluation. DSCN, DIAL, Paris, $95 \mathrm{p}$.

[4] Roitman, J. (1990) The Politics of Informal Markets in Sub-Saharan Africa. The Journal of Modern African Studies, 28, 671-696. https://doi.org/10.1017/S0022278X00054781

[5] Raisonj (1993) Les formes spatiales de l'incertitude en Afrique contemporaine, Espares Les actes de langage. Hermann, Paris. https://doi.org/10.3406/tigr.1993.1610

[6] Austin, J.-L. (1979) Quand dire c'est faire. Seuil, Paris. 
[7] Rogers, S.J. (1972) Les actes de langage. Hermann, Paris.

[8] Milner, C. and Borkakoti, J. (1997) International Trade and Labour Markets. Palgrave Macmillan, London. https://doi.org/10.1007/978-1-349-14577-5

[9] Bairoch, P. (1996) Commerce extérieur et développement économique de l'Europe au XIXème siècle. éd. Mouton, Paris.

[10] Crozet, M. (2004) Do Migrants Follow Market Potentials? An Estimation of a New Economic Geography Model. Journal of Economic Geography, 4, 445.

https://doi.org/10.1093/jeg/4.4.439

[11] Krugman, P. (1984) La Mondialisation n'est pas coupable: Vertus et limites du libre-échange. éd. La Découverte, Paris.

[12] Musonda, J.C. (2019) Les échanges commerciaux de la RDC sur le marché européen enjeux, opportunités et perspectives, de 2000 à 2010. Thèse de doctorat, Université de Lubumbashi, Kinshasa.

[13] Lancaster, T. (1984) The Analysis of Re-Employment Probabilities for the Unemployed. Journal of the Royal Statistical Society: Series A (General), 143, 141-152. https://doi.org/10.2307/2981986

[14] Eaton, J. and Kierzkowski, H. (1984) Oligopolistic Competition, Product Variety, Entry Deterrence, and Technology Transfer. The RAND Journal of Economics, 15, 102. https://doi.org/10.2307/3003672

[15] Yin, R.K. (2012) Applications of Case Study Research. Sage Publication, London.

[16] Mankiw, G., et al. (2013) Principes de l'économie. éd. De Boeck, Paris, 342.

[17] Gerusalmy, O. (2017) Fraude fiscale en Belgique, avril Article.

[18] Pires, A. (1997) Échantillonnage et recherche qualitative: Essai théorique et méthodologique. Criminologue, École de criminologie, Université d'Ottawa, Ottawa.

[19] http://www.transparency.org/cpi

[20] Gourguecho, G. (2016) Fraude et évasion fiscales, aggravation des injustices, affaiblissement de la démocratie le POSSIBLE N16.

[21] Raffestin, C. and Guichonnet, P. (1974) Géographie des frontières. PUF, Paris, 222 p.

[22] Velasco-Graciet, H. (1998) La frontière, le territoire et le lieu, norme et transgression dans les Pyrénées Occidentales. Thèse, Université de Pau et des pays de l'Adour, 506 p. 